\title{
REPRODUCTIVE ISOLATION BY DIFFERENT TIME OF DRONE FLIGHT BETWEEN APIS CERANA FABRICIUS, 1793 AND APIS VECHTI (MAA, 1953)
}

N. KOENIGER *, G. KOENIGER *, S. TINGEK ${ }^{* *}$, M. MARDAN *** and T.E. RINDERER ****

* Institut für Bienenkunde (Polytechnische Gesellschaft) Fachbereich Biologie, Universität Frankfurt/Main, Karl-von-Frisch-Weg 2, D 637 Oberursel, F.R. GERMANY

** Honeybee Research Section, Agricultural Research Station Tenom, SABAH; MALAYSIA

*** University Pertanian Malaysia, Serdang, Selangor, MALAYSIA

Honey-bee Breeding, Genetics \& Physiology Research ARS; USDA; 1157 Ben Hur Road,

Baton Rouge, Louisiana 70808. USA

\section{SUMMARY}

In Sri Lanka the three honeybee species Apis florea, Apis cerana and Apis dorsata are found in the same biotope. The daily periods of drone flight were found to be specific (KoENIGER and WuaYagunaseKERA, 1976). According to RUTTNER (1988) this behavioral isolation is a more complete separation than the reproductive barrier between $A$. mellifera and $A$. cerana.

The three honeybees, $A$. cerana, $A$. vechti and $A$. dorsata are naturally distributed in the same habitat. We compared the time of drone flight between these honeybees in Sabah (North East Borneo).

\section{MATERIAL AND METHODS}

The observations were carried out from Feb. 16 to Feb. 18 in Tenom, Sabah, Malaysia. Nine colonies of $A$. vechti were inspected. But only one colony (No. G 21) contained several drones. We observed this colony from $10.00 \mathrm{~h}$ to $19.00 \mathrm{~h}$ during two days (Feb. 16, Feb. 17). All drones leaving and returning to the colony were counted. The number of flights were noted in 15 minutes intervals.

In $A$. cerana we had three colonies with drones which were watched on three days (Feb. 16, Feb. 17, Feb. 18) from $11.00 \mathrm{~h}$ to $19.00 \mathrm{~h}$.

We found two $A$. dorsata colonies with drones. Both colonies were built in a palm tree at a height of 7 meters. The distance between the observer and the colonies was 5 meters. The drones were clearly recognized by their specific shape against the sky. Workers have a tipped abdomen and the end of the 
drone's abdomen is blunt. Further drones have a distinct flight sound much louder than the flight noise of workers. Both colonies were observed on Feb. 17 and Feb. 18.

\section{RESULTS AND DISCUSSION}

The drone flight of $A$. cerana occurred between $13.45 \mathrm{~h}$ and $15.30 \mathrm{~h}$. We observed 258 flights. The drones of $A$. vechti started their flight activity at $16.15 \mathrm{~h}$. That was 45 minutes after the last drone of $A$. cerana had returned. We counted 205 drone flights of $A$. vechti. The activity ceased at $18.15 \mathrm{~h}$. At this time $A$. dorsata drones started their flight activity. They began with a sudden start of more than 250 drones and it ended abruptly at $19.00 \mathrm{~h}$ when the latest drones returned to the comb. In $A$. dorsata we estimated the number of flights to be 1730 .

In fig. 1 the percentage of the drone flights per 15 minutes is plotted. It clearly shows the complete separation between $A$. cerana and $A$. vechti. The small overlap between. $A$ dorsata and $A$ vechti does not imply a possibility of interspecific copulations.

Our observations showed that the latest drones of vechti were returning while the first drones of dorsata started.

\section{$\%$ DRONE FLIGHTS}

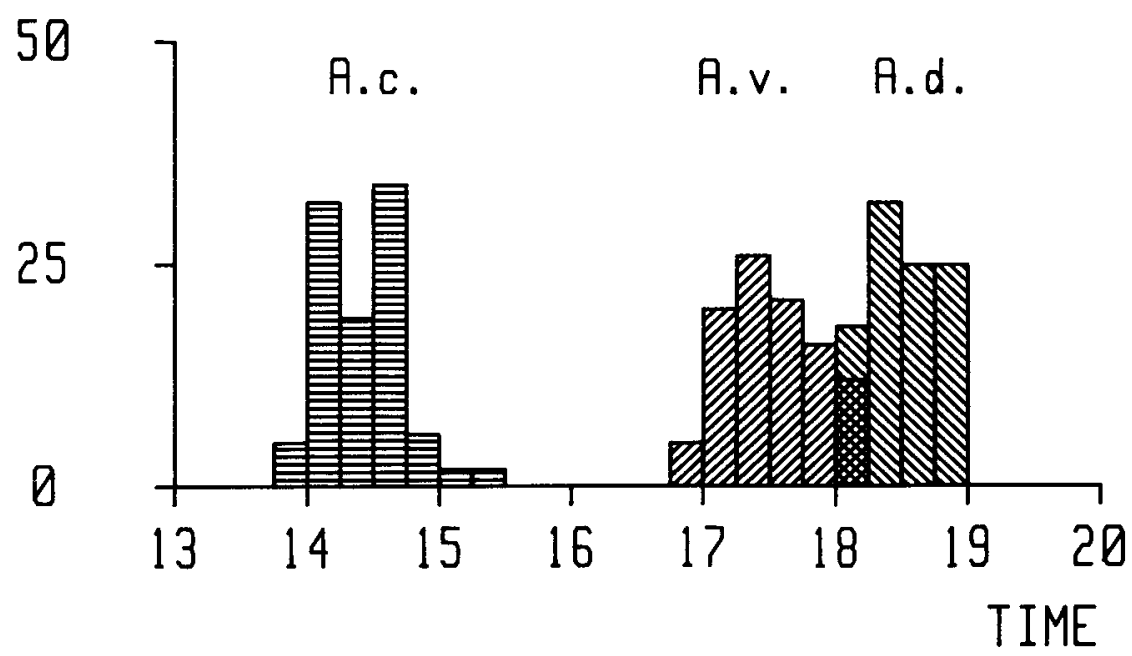

FIg. 1. - Time of drone flight of Apis cerana (A.c.) Apis vechti (A.v.) and Apis dorsata (A.d.). 
The specific times of drone flights described here give evidence of a complete reproductive isolation. Therefore, Apis cerana and Apis vechti must be ranked systematically as well separated species.

Received for publication in March 1988. Accepted for publication in March 1988.

\section{ACKNOWLEDGEMENTS}

We want to thank Mr. M. T. Tulas, officer in charge, Agricultural Research Station Tenom, for his valuable support. Mr. Anasthasius KaLITU kindly helped us inspecting the bee colonies. University Pertanian Malaysia and University of Guelph, Canada invited the German and US authors to Malaysia thus providing the basis to this cooperation.

\section{RÉSUMÉ}

ISOLEMENT REPRODUCTIF ENTRE APIS CERANA FABRICIUS, 1793

ET APIS VECHTI (MAA, 1953) DÚ Aं L'HEURE DIFFERENTE DE VOL DES MÂLES

Les mâles d'Apis vechti sortent pour leur vol nuptial entre $16 \mathrm{~h} 45$ et $18 \mathrm{~h} 15$. Les autres espèces présentes dans la région, Apis cerana et Apis dorsata, ont leur vol nuptial à des heures totalement différentes. On peut ainsi prouver l'existence d'un isolement reproductif et par conséquent reconnaître Apis vechti en tant qu'espèce propre.

\section{ZUSAMMENFASSUNG}

\section{REPRODUKTIVE ISOLATION ZWISCHEN APIS VECHTI UND APIS CERANA DURCH UNTERSCHIEDLICHE DROHNENFLUGZEIT}

Die Drohnen von Apis vechti fliegen zwischen $16.45 \mathrm{~h}$ und $18.15 \mathrm{~h}$ auf Paarungsflug. Die im gleichen Gebiet vorkommenden anderen Arten Apis cerana und Apis dorsata haben deutlich verschiedene Paarungsflugzeiten. Auf diese Weise konnte eine reproduktive Abgrenzung und damit der systematische Status einer eigenen Art für Apis vechti nachgewiesen werden.

\section{LITERATURE}

Koeniger N., Wijayagunasekera H.N.P., 1976. - Time of drone flight in the three Asiatic honeybee species (Apis cerana, Apis florea, Apis dorsata). J. Apic. Res., 15 (2), 67-71.

RUTTNER F., 1988. - Biogeography and taxonomy of honeybees. Springer Verlag, Berlin, 284 p. 